\title{
Studia
}

SYNCHRONICZNE I DIACHRONICZNE ASPEKTY BADAŃ POLSZCZYZNY

www.wnus.edu.pl/sj | DOI: 10.18276/sj.2016.15-02 | 19-37

\section{MiROSŁAWA BIAŁOSKÓRSKA}

Uniwersytet Szczeciński, Wydział Filologiczny

Szczecin

\section{Strukturalno-semantyczna analiza słownictwa z komponentem nazwy barwy złotej w lirykach Leopolda Staffa (część trzecia) ${ }^{1}$}

\author{
Słowa kluczowe \\ idiolekt poety, słowotwórstwo, barwa złota
}

Keywords

poet's idiolect, word formation, the colour (hue) of gold

1. Leopold Staff (1878-1957) to poeta, dramaturg i tłumacz, którego dorobek literacki przypada na kilka epok w literaturze polskiej. Mimo zmian ogłaszanych w manifestach programowych kolejnych prądów w literaturze pierwszej połowy XX wieku, poeta potrafił dostosować swój warsztat artystyczny, zyskując uznanie, często sympatię wielu młodych pisarzy i poetów tamtego czasu, wśród których byli: Julian Tuwim, Tadeusz Różewicz, Krzysztof Kamil Baczyński i wielu innych². Liryki Staffa zachwycają harmonią zachodzącą między tematem utworu, pięknem języka poetyckiego i dużym znawstwem walorów

${ }^{1}$ Część pierwsza cyklu: Obrazy poetyckie z komponentem barwy złotej w lirykach Leopolda Staffa, w: Barwa w języku, literaturze i kulturze, t. 4, pod red. E. Komorowskiej i D. Stanulewicz, Szczecin 2013, s. 71-84; część druga: Stratyfikacja słownictwa z komponentem nazwy barwy złotej w lirykach Leopolda Staffa, „Studia Językoznawcze”. Synchroniczne i diachroniczne aspekty badań polszczyzny, Szczecin 2015, t. 14.

2 Pisze o tym I. Maciejewska w obu częściach monografii pt. Leopold Staff. Lwowski okres twórczości, Warszawa 1965 i Leopold Staff. Warszawski okres twórczości, Warszawa 1973. 
estetycznych, według których malowane są obrazy z życia ludzi i natury. Irena Maciejewska tak o tym między innymi pisze: „Natura i kultura są źródłem i zarazem sprawdzianem piękna i dobra. Uczą mądrości i dostarczają wrażeń estetycznych. W ich tle umieszcza też Staff bohaterów swej liryki. Tyle że zarówno naturę, jak kulturę widzi przez pryzmat konwencji kulturowych"3.

Tabela. Struktura form wyrazowych

\begin{tabular}{|c|c|c|c|c|}
\hline Lp. & Nazwa części mowy i liczba użyć & $\begin{array}{c}\text { Liczba } \\
\text { użyć } \\
\text { tekstowych }\end{array}$ & $\begin{array}{l}\text { Lek- } \\
\text { semy }\end{array}$ & $\%$ \\
\hline 1. & 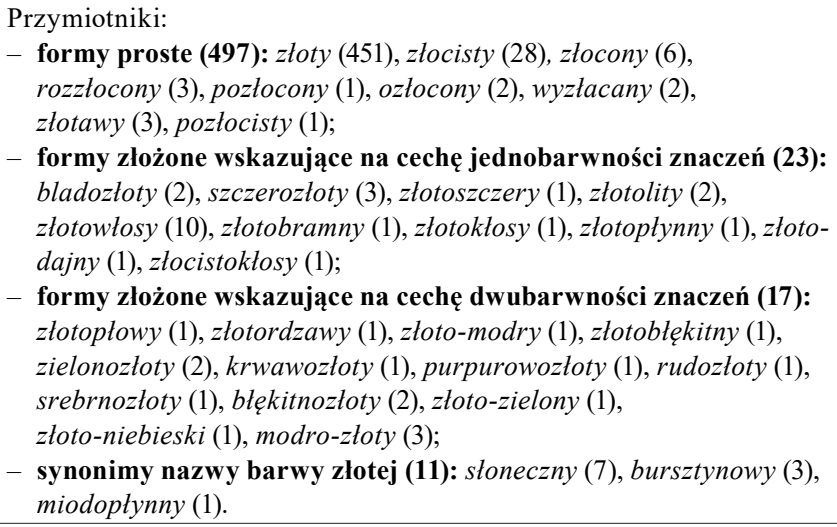 & 548 & $\begin{array}{l}13 \\
3\end{array}$ & 74,12 \\
\hline 2. & $\begin{array}{l}\text { Rzeczowniki: } \\
\text { - formy proste (120): złoto (113), pozłota (4), złocenie (1), } \\
\quad \text { złocistość (1), pozłótka (1); } \\
\text { - formy złożone (5): złotogłów (4), brzęczyzłotka (1); } \\
\text { - synonimy nazwy barwy (17): topaz (2), bursztyn (7), } \\
\quad \text { blask topazu (1), topazy ogni (1), miód słońca (1), stopić w topaz (2), } \\
\quad \text { tunika miodopłynna (1), jaskrzyce pożogi (1), mosiądze zachodów (1). }\end{array}$ & 142 & $\begin{array}{l}16 \\
5 \\
2\end{array}$ & 19,24 \\
\hline 3. & $\begin{array}{l}\text { Czasowniki: } \\
\text { - formy w stronie czynnej (29): złocić (10), ozłocić/ozłacać (14), } \\
\quad \text { pozłocić/pozłacać (3), przezłacać się (1), rozzłocić (1); } \\
\text { - formy w stronie zwrotnej (18): złocić się (17), rozzłacać się (1); } \\
\text { - imiesłowy przysłówkowe współczesne (2): złocac się (1), złocac (1). }\end{array}$ & 49 & $\begin{array}{l}11 \\
7 \\
2 \\
2\end{array}$ & 6,64 \\
\hline \multicolumn{2}{|r|}{ Razem } & 739 & 62 & 100,00 \\
\hline
\end{tabular}

Celem rozważań w tym artykule będzie spojrzenie na strukturę słownictwa z pola barwy złotej, opisanie budowy słowotwórczej rodziny wyrazu złoty (derywaty proste, złożone) oraz budowy synonimów tej barwy. Poeta użył w osiemnastu zbiorkach poezji ${ }^{4}$ 62 leksemów (739 użyć) z komponentem tej barwy lub w formie poetyzmów semantycz-

3 I. Maciejewska, Leopold Staff. Lwowski okres twórczości, s. 305.

${ }^{4}$ L. Staff, Poezje zebrane, t. 1-2, Warszawa 1967. W cytatach wymienia się tytuł wiersza i skrót zbiorku, w którym wystąpił badany wyraz. 
nych ${ }^{5}$. Tabela zawiera zestawienie wszystkich leksemów, które będą podlegały analizie słowotwórczo-semantycznej.

2. Wśród 62 leksemów tylko dwa wyrazy: przymiotnik złoty (451×) i rzeczownik złoto $(113 \times)$ mają budowę prostą, złożoną z rdzenia złot- i morfemów fleksyjnych: - $y,-a$. Pozostałe wyrazy to różnorodne derywaty słowotwórcze: przymiotnikowe (32 wyrazy), rzeczownikowe (6 wyrazów) i czasownikowe (11 wyrazów) oraz synonimy nazwy barwy złotej, które pomijam w tym opisie. W skład przymiotników wliczone zostały imiesłowy przymiotnikowe, zaś w grupie derywatów czasownikowych znajdują się dwa imiesłowy przysłówkowe współczesne (patrz tabela).

Obserwacja formacji słowotwórczych z rdzeniem/tematem słowotwórczym -złot- pozwala stwierdzić, że poeta za ich pomocą mógł wyrazić: a) stopień osłabienia lub natężenia barwy (przymiotniki gradacyjne); b) istotę jakości barwy w relacji z określanym rzeczownikiem (np. przymiotniki jakościowe); c) zjawisko występowania stanu barwy (wykorzystanie czasowników stanowych, rzeczowników dewerbalnych); d) stopień metaforyzacji syntetycznych form przymiotnikowo-rzeczownikowych w miejsce grup nominalnych, co wpłynęło na ekonomię wypowiedzi poetyckiej. Zarysowane tu mechanizmy urozmaicenia zasobu słownikowego tekstów poetyckich Leopolda Staffa wyrażają nową wartość semantyczną członów badanych derywatów.

\section{Przymiotnikowe derywaty gradacyjne jako modulatory intensyfikacji} lub osłabienia cechy

Krystyna Kallas pisze: „przymiotniki gradacyjne oznaczają intensyfikację lub osłabienie cechy nazwanej przymiotnikiem stanowiącym podstawę słowotwórczą”ø. W badanym materiale funkcję osłabienia cechy pełni sufiks - awy w derywacie zlotawy i pierwszy człon jednobarwnego złożenia bladozłoty. Przymiotnik zlotawy $(3 \times)$ wystąpił w zwrotce wiersza Pogoda jesienna jako jeden z kilku wyznaczników barwy wschodzącego słońca: Jak krąg mlecznego, matowego szkła, Przez który świeci mdto ztotawy płomień,/ Stońce bladego, spóźnionego wschodu/ Rozwłócza śpiacy i oślepły promień (Dzień I, 297)7. Po raz drugi derywat złotawy został użyty w liryku Ruiny Palatynu na określenie więdnącej róży: W pomrok twej biblioteki, przez otwór stropu okragty,/ Blada róża zlotawa rzuca w głąb płatki więdnace (Uśmiechy I, 811). Trzecie użycie znalazło się w wielozwrotkowym wierszu re-

5 Przez poetyzm semantyczny rozumiem za Teresą Skubalanką: ,nazwy przedmiotów estetycznie wartościowych, najczęściej pięknych”, do których należą nazwy kamieni szlachetnych, minerałów, niektórych ciał niebieskich, kwiatów itp., w: eadem, O stylu poetyckim i innych stylach języka, Lublin 1995, s. 25.

${ }^{6}$ K. Kallas, Derywaty gradacyjne, w: Gramatyka współczesnego języka polskiego. Morfologia, cz. 2, pod red. R. Grzegorczykowej, R. Laskowskiego, H. Wróbla, wydanie drugie zmienione, Warszawa 1998, s. 502.

7 Za skrótem tytułu zbiorku cyfra rzymska wskazuje tom (dwutomowego wydania wierszy), cyfra arabska odsyła do strony, na której znajduje się cytat. 
fleksyjnym Wychodźcy, w którym poeta nakreślił obrazy zniszczeń powstałe po pierwszej wojnie światowej i wymęczonych znojami wojny ludzi wracających do domów: Każdy niesie pod powieka/ Skrawek ziemi - gdzieś daleko!/ Mały ziemi szmat ma w oczach:/ Jakaś strzechę w brzóz warkoczach,/ Jakąś studnię na podwórzu,/ Jakiś płot w zlotawym kurzu (Tęcza II, 52).

Przymiotnik odprzymiotnikowy złotawy ze względu na wartość semantyczną sufiksu -awy wyraża w pierwszych dwu przykładach słabe natężenie barwy złotej, jej niedobór wynikający z naturalnej przeszkody, którą jest np. mleczne, matowe szkło, przez które świeci mdło złotawy płomień lub słabe oświetlenie biblioteki, w którym blada złotawa róża więdnie i gubi płatki. Epitety nominalne złotawy płomień i złotawa róża ze względu na podstawową wartość semantyczną barwy złotawy mają waloryzację dodatnią ${ }^{8}$, jednak w obu cytatach ich wartość naddaną obniżają użycia kontekstowe (płomień świeci mdło, róża rzuca w głąb płatki więdnące), dlatego możemy, na podstawie obu przykładów, mówić o podwójnej waloryzacji: dodatniej semantycznej oraz kontekstowej - obniżającej znaczenie podstawowe przymiotnika złotawy. Trzecie użycie derywatu $\mathrm{w}$ epitecie nominalnym złotawy kurz posiada podwójną waloryzację dodatnią, oddaną w refleksyjnym i patriotycznym opisie umęczonych wojną ludzi i zniszczeń materialnych spowodowanych przez wojnę.

Modulatorem osłabienia cechy barwy złotej jest w złożeniu przymiotnikowym bladozloty $(2 \times)$ pierwszy człon złożenia blady. Poeta po raz pierwszy użył tego derywatu w tomiku Ptakom niebieskim z 1905 roku, który, wśród 18 zbiorków poezji, wyróżnia największy stopień zagęszczenia nazw barwy złotej (99 form gramatycznych, 17 leksemów, 13,4\% wśród 739 wszystkich użyć). W pierwszej czterowersowej zwrotce wiersza Szron czytamy: Bladozłoty, senny,/ Skryty w modrych mgłach,/ Pierwszy chtód jesienny/ Posiał szronem strach. (Ptakom I, 411). Na tym przykładzie widać równocześnie skłonność pisownianą Staffa do stosowania szeregowo zestawianych przymiotników, które to zjawisko jest jedną z wielu cech jego warsztatu artystycznego. Drugie użycie złożenia przymiotnikowego bladozłoty wystąpiło w zbiorku $W$ cieniu miecza (1911). W wierszu O zmierzchu czytamy: W ogromnej, świętej ciszy krag stońca umiera/ Różowiąc nieboskłony zorza bladoztotą. (W cieniu I, 846). Obie metafory o właściwościach sytuacyjnych dookreślają poetyckie obrazy zjawisk atmosferycznych (jesienny chłód, zorza o zachodzie słońca), nadając obrazom wertykalno-horyzontalny układ zdarzeń.

Przymiotnikowe derywaty jakościowe wyrażające cechę przedmiotu określanego Wyznacznikiem jakości cechy barwy jest sufiks $-i s t y^{9} \mathrm{w}$ derywacie odprzymiotnikowym zlocisty (28×). Właściwość semantyczną tego przymiotnika potwierdza Słownik warszaw-

${ }^{8} \mathrm{O}$ dodatniej waloryzacji barwy złotej w tekstach lirycznych pisze obszernie Ryszard Tokarski, w: Semantyka barw we współczesnej polszczyźnie, Lublin 1995, s. 116-119.

${ }^{9}$ Przymiotnik złocisty z sufiksem -isty odnotowany został już w Pamiętniku Janczara, napisanym między 1496 a 1501 r. (I. Winkler-Leszczyńska, Sufiksy przymiotnikowe -ity, -isty, -aty, -asty w języku 
ski, gdzie w pierwszym znaczeniu podaje się 'złoty, szczerozłoty, złotolity', 2. 'złocony, pozłocony, pozłocisty’ z cytatem papier złocisty $=$ koloru złota (SW VIII, 528) ${ }^{10}$. Wśród 60 derywatów z rdzeniem złot- jest to najczęściej wykorzystywany derywat odprzymiotnikowy, który odnosi się do zjawisk przyrody ożywionej i nieożywionej, ale również dookreśla przedmioty kultury materialnej. Oto niektóre przykłady użyć w podziale znaczeniowym:

- dookreślenie elementów przyrody ożywionej: złocisty wyrój pszczót (Gałąź I, 698), pszenicznych pól zlociste tany (Mistrz I, 133), złociste listowie (Uśmiechy I, 715);

- dookreślenie elementów przyrody nieożywionej: złocisty piach gwiazd (W cieniu I, 926), księżyc jak dysk złocisty efeba (Uśmiechy I, 795), snop złocistych promieni (Dzień I, 378), złociste stońce (Ptakom I, 508), złociste zorze (Łabędź I, 1051), złociste dni (Ucho II, 535, 2×);

- dookreślenie nazw napojów: złocisty sok wina (Sowim II, 275), złociste wino (Ścieżki II, 227), złocista oliwa (Żywiąc II, 451);

- dookreślenie elementów kultury materialnej: złociste pieczęcie (W cieniu I, 923), złociste drzwi (Sny I, 67), złociste oltarze (Dzień I, 364), złocista odzież (Ptakom I, 522).

W przytoczonych grupach nominalnych derywat odprzymiotnikowy złocisty jest zazwyczaj określeniem rzeczowników konkretnych, niekiedy jednak łączy się z rzeczownikiem abstrakcyjnym, tworząc poetycką personifikację, jak w cytacie: zlocista melancholia pogodnego słońca (Gałąź I, 581). Na uwagę zasługuje ponadto jednokrotnie użyty przez poetę derywat odprzymiotnikowy poztocisty z prefiksem po- w znaczeniu kontekstowym: odarty z poztocistej zbroi pretoriańskiej (Martwa II, 734), gdzie rzeczownik zbroja dookreślają dwa przymiotniki: jakościowy - pozłocista i posesywny - pretoriańska. Podobną funkcję pełni złożenie zlotolity $(2 \times)$ w znaczeniach kontekstowych: zlotolita czara (Ścieżki II, 194) i zlotolity tron (Mistrz I, 160), czyli czara i tron wykonane $z$ litego złota oraz jednokrotnie użyte złożenie szczerozłoty w cytacie: szczerozłote puchary nalane winem (Żywiąc II, 450), z parafrazą 'wykonane ze szczerego złota'.

Przymiotnikowe derywaty symilatywne wobec określanych rzeczowników

Symilatywną wartość semantyczną wobec określanej podstawy rzeczownikowej mają rzadko używane przez poetę jednobarwne złożenia przymiotnikowe: szczerozłoty $(2 \times)$ oraz singularium ztotoszczery $(1 \times)^{11}$. W połączeniach syntaktycznych: zorza szczeroztota (Sny I, 33), szczeroztoty promień słońca (Sny I, 71) oraz gwiazda piękna ztotoszczera (W cieniu I, 898) przymiotniki szczerozłoty, złotoszczery mają użycie porównawcze wobec rzeczowni-

polskim na tle ogólnostowiańskim, Ossolineum 1964, s. 15).

${ }^{10}$ Słownik języka polskiego, pod red. J. Karłowicza, A. Kryńskiego, W. Niedźwiedzkiego, t. 1-8, Warszawa 1900-1927 (dalej SW).

${ }^{11}$ Zlotoszczery z kwalifikatorem „rzadki” 'szczerozłoty, złotolity’ (SW VIII, 537). 
ków określanych: zorza, gwiazda i promień słońca, które stały się członami porównywanymi o parafrazach 'podobne do szczerego złota' lub ‘jak szczere złoto'.

Imiesłowy przymiotnikowe bierne wyrażające posiadanie cechy nazwanej przez czasownik stanowy

Od czasowników stanowych: złocić, ozłocić, pozłocić, rozzłocić, wyzłacać zostało utworzone 5 imiesłowów przymiotnikowych biernych: zlocony $6 \times$, ozłocony $2 \times$, poztocony $1 \times$, rozzlocony $3 \times$, wyztacany $2 \times$, typowymi dla tych form sufiksami -ony/-any. Zastosował je poeta $\mathrm{w}$ opisie obrazów:

- przyrody ożywionej: (cyprys) ozłocony wieczornym stońcem (Uśmiechy I, 812);

- przyrody nieożywionej: słoneczne południe ztocone (Gałąź I, 613), rozzłocone potudnie (słoneczne, omdlałe) (Sny I, 46), rozzłocona jaśń (Mistrz I, 165), rosy ozłocone blaski słonecznymi (Mistrz I, 148);

- elementów kultury materialnej: przedziwna zlocona czara (Sowim II, 275); litery grubo zlocone (Barwa II, 723), (okna) ztocone świattem stońca (Sny I, 37), szprychy słońcem wyzlacane (Ścieżki II, 165), trumna pozłocona (Mistrz I, 168).

Zastosowane przez poetę derywaty imiesłowowe w funkcji określeń rzeczowników: cyprys, południe, jaśn, rosa, okna, szprychy wpłynęły na zmianę ich wartości semantycznej, tworząc barwne metafory poetyckie o budowie grup nominalnych. W połączeniach: złocona czara, litery złocone, pozłacana trumna imiesłowy bierne występują zaś w znaczeniu 'to, co zostało pokryte złotem'.

Derywaty czasownikowe jako określenia stanów przyrody, rzadziej innych elementów świata przedstawionego wierszy

Derywaty czasownikowe na tle pozostałych derywatów z komponentem nazwy barwy złotej stanowią mało liczną reprezentację użyć tekstowych w lirykach poety, co ilustruje tabela. Do najczęściej przywoływanych czasowników należą: złocić (10×), zlocić się (17×) oraz ozłacać/oztocić (14×). Zaledwie trzykrotnie wystąpił wariant pozłocić/pozłacać, pozostałe pięć derywatów (przezłacać się, rozzłocić, rozzłacać się, złocac, złocąc się) to singularia w wierszach Staffa, obecne również w SW.

Derywat złocić tworzy często strukturę syntaktyczną typu: słońce/promień słońca złoci co: mendle snopów (Ścieżki II, 231); nie ma czego (Sny I, 71); chłody wód (Ptakom I, 454); świat (Gałąź I, 600); drzew szczyty (Uśmiechy I, 747); ciche wody (Łabędź I, 1099). $\mathrm{W}$ innych połączeniach syntaktycznych podmiotem związku nie jest słońce, lecz rzeczownik w znaczeniu przenośnym kontekstowym, co tworzy schemat: X złoci co: pogoda (odblaskiem czoła swego) złoci ciche pola (Dzień I, 378); lato złoci pól rozłogi (Gałąź I, 606); wrzesień złoci liście (Sowim II, 326); cisza zmierzchu złoci wszystko (Ucho II, 465); zachód złoci świat mosiądzem (Wysokie II, 595). We wszystkich przykładach frazy z czasowni- 
kiem stanowym świeci są poetyckimi personifikacjami, w których podmioty wyrażone rzeczownikami nieosobowymi zyskują rolę osoby.

Podobne konotacje semantyczne występują w połączeniach z czasownikami ozłocić/ ozłacać, w których fraza przyjmuje strukturę: stońce/blask słońca ozłoci/ozłaca co: senna ziemię (Ścieżki II, 136); rogi wołom (Ptakom I, 485); łan (Ptakom I, 566); młodość nieba (Łabędź I, 1050); krew zorzy (Sowim II, 273); szczyty drzew (Ucho II, 512); równinę (Wysokie II, 589); słońca oko ozłoci ziemię blaskiem (Sowim II, 242). Drugi typ połączeń tworzy frazy: X ozłoci/ozlaca co: pragnienie uciszone ozłaca wspomnieniem i pamięcia (Gałąź I, 661); zorza zachodnia ozłaca pola, drogi, rowy (Ucho II, 481); świt ozłoci wschód (Barwa II, 608). W tej grupie podmiot zawarty we frazie jest sprawcą jakiegoś zjawiska świetlnego, tworząc oryginalne metafory.

Najczęściej występujący w badanym materiale czasownik zwrotny złocić się znajduje się w konstrukcjach medialnych, które Roman Laskowski określa jako „oznaczające czynność wykonywaną przez agensa ku jego własnemu pożytkowi (dla siebie samego)"12. Analizowane frazy mają więc strukturę syntaktyczną typu: X (dla siebie samego) zloci się, co ilustrują dla przykładu użycia tekstowe: błoń się złoci (Ścieżki II, 127); blaskiem złoci się świetlica (Ścieżki II, 204); w krwi stu słońc wschód złoci się (Ptakom I, 406); złoca się szczyty drzew (Gałąź I, 633); kłosy złoca się w słońcu (Gałąź I, 688); przyroda złociła się spokojem słońca (Tęcza II, 40); w dojrzałych sadach złoci się plon bogaty (Sowim II, 282); złoca się lipy, brzozy, kasztany, jawory (Wysokie II, 573); liście się złoca w sto odcieni (Martwa II, 791). Zarówno wartość semantyczna czasownika złocić się, jak i przymiotnika złoty najczęściej wynika z prototypowego odniesienia barwy do słońca, dlatego przytoczone cytaty oraz pozostałe użycia tekstowe z tym czasownikiem posłużyły poecie do kreacji obrazów świetlnych z elementami przyrody ożywionej i nieożywionej, gdzie złoca się: błoń, świetlica, szczyty drzew, kłosy, przyroda, plon bogaty, liście i różnorodne drzewa w roli metaforycznych agensów.

Podczas gdy czasowniki: złocić, złocić się, ozlacać/ozłocić wyróżnia szeroki zakres występowania w polszczyźnie powszechnej, obiegowej, kolejne sześć form to wyrazy rzadkie (pozłocić/pozłacać $3 \times$ ) lub artystyczne singularia poety (przezłacać się, rozzłocić, rozzłacać się, złocąc, złocąc się). Z ilustracji źródłowej wynika, że wystąpiły jako zjawisko świetlne w kreacji przyrody otaczającej człowieka, np.: ścierń pozłaca brązem doliny i wzgórza (Ścieżki II, 185); wrześniowe stońce pozłaca (Ptakom I, 415); świat zaczyna się przeztacać (Łabędź I, 1080); rozzłoci ją (strzechę) stoma (Dzień I, 375); błonie rozzlaca się w skrach (Mistrz I, 130); (wieczór) zlocąc źdźbła przyziemne (Gałąź I, 671); lilie złocac się w słońca zachodzie (W cieniu I, 852).

12 R. Laskowski, Paradygmatyka. Czasownik, w: Gramatyka wspótczesnego języka polskiego. Morfologia, cz. 1, Warszawa 1998, s. 191-192. 
Gdy porównamy funkcje barwy złotej w twórczości poetyckiej Adama Mickiewicza ${ }^{13}$, Stanisława Grochowiaka ${ }^{14}$, Zbigniewa Herberta ${ }^{15}$, Marii Pawlikowskiej-Jasnorzewskiej ${ }^{16}$ i Juliana Tuwima ${ }^{17}$ z wystąpieniami badanych tu rzadkich lub pojedynczych użyć czasowników stanowych u Staffa, to pozłocić/pozłacać rejestruje jednokrotnie tylko SJAM, Marzena Kurek odnotowała czasownik rozzłocić u Grochowiaka, zaś czasowniki w stronie zwrotnej: rozzłocić się, przezłacać się oraz imiesłowy współczesne złocac, złocąc się występują tylko u Staffa. Z kolei omówione wcześniej obiegowe w polszczyźnie ogólnej czasowniki złocić, złocić się, ozłocićlozłacać odnotowują wraz ze Staffem wszyscy przywołani tu poeci w licznych użyciach tekstowych ${ }^{18}$.

\section{Rzeczownikowe derywaty w funkcji podmiotu lub określenia}

Rzeczownik zloto (113 użyć tekstowych) najczęściej występuje w lirykach poety w funkcji nazwy barwy złotej, pozostałe 6 derywatów to Staffowskie singularia artystyczne (poztótka 1×, brzęczyzłotka 1×, złocenie 1×, ztocistość $1 \times$ ) lub wyrazy rzadko używane (poztota 4×, zlotoglów 4×). Derywat pozłótka ${ }^{19}$ został użyty w wierszu Odkrywca złotych światów, np.: Tęskniąc jako łódź w przystani,/ Począł malować w izbie swej pyłem pozłótki/ Drzwi, tóżko, krzesło (Ptakom I, 434) w funkcji stylistycznej jako gwarowa nazwa środka czynności utworzona sufiksem - $k a$ od podstawy czasownikowej pozłocić. Od tego samego czasownika powstał derywat paradygmatyczny pozłota o parafrazie 'to, co zostało pozłocone' / 'to, co stało się pozłocone', np.: słońce spylone nalotem pozłoty (Mistrz I, 178); ryby skrzace poztota tusek (Ptakom I, 487); przygasa niebiosów pozłota (Gałąź I, 651); blask stat się podobny pozłocie (Żywiąc II, 375). Ze zjawiskiem nominalizacji czasownika złocić mamy do czynienia w derywacie złocenie (sufiks -enie), który wystąpił w wierszu W mroku: Czary skalanych dusz miłościa oceń,/ Zmyj łza, niech błysna blaskiem cudnych złoceń

13 Ze Słownika języka Adama Mickiewicza (pod red. K. Górskiego i S. Hrabca, t. 1-11, Wrocław 1962-1983) wybrałam 20 leksemów z komponentem barwy złotej w 100 użyciach tekstowych (dalej SJAM).

14 M. Kurek, Kolor w poezji Stanisław Grochowiaka, „Poznańskie Studia Polonistyczne”. Seria Językoznawcza, Poznań 1997, s. 132-147. Autorka objęła badaniem 8 zbiorków poety, z których wybrała 86 użyć barwy złotej (najwięcej ze wszystkich barw).

${ }^{15}$ E. Badyda, Świat barw - świat znaczeń w języku poezji Zbigniewa Herberta, Gdańsk 2008. Ze wszystkich zbiorków poezji Herberta autorka wybrała 111 nazw barw w 629 użyciach, wśród których barwa złota zajmuje 6. lokatę z 30 użyciami tekstowymi 6 nazw.

16 J. Rychter, Językowa kreacja barw w poezji Marii Pawlikowskiej-Jasnorzewskiej, Szczecin 2014, s. 262. Autorka wybrała 32 leksemy barwy złotej w 286 użyciach tekstowych.

17 A. Seniów, Barwa złota w utworach lirycznych Juliana Tuwima, „Studia Językoznawcze”. Synchroniczne diachroniczne aspekty badania polszczyzny, Szczecin 2012, t. 11, s, 187-207. Autorka wybrała 27 leksemów z pola złota w 110 użyciach tekstowych.

18 Występujące w lirykach Leopolda Staffa 62 leksemy z komponentem barwy złotej zestawiłam z przywołanymi tu pięcioma poetami w artykule: M. Białoskórska, Stratyfikacja słownictwa z komponentem nazwy barwy złotej...

19 Pozlótka gwar. 'pozłacanie, złocenie' (SW IV, 914). 
(Dzień I, 311). Z kolei rzeczownik abstrakcyjny zlocistość, utworzony sufiksem -ość od podstawy przymiotnikowej złocisty, został użyty w wierszu Hymn do barw, który zawiera credo poetyckie Staffa na temat wartości barw w kreacji świata przedstawionego. Oto krótka próbka tekstu: Czyli sok wina albo miąższ brzoskwini/ Byłby rozkosza, jaka sercu czyni,/ Bez złocistości płynu, bez opusza 20/ Owocu (Żywiąc II, 398). Interesująca jest budowa Staffowskiego neologizmu artystycznego brzęczyzlotka z sufiksem -ka o parafrazie 'ta, która brzęczy jak złoto i jest złota’ na określenie pszczoły w wierszu Hora tańczaca: Szum twych szat, w którym szeptał szmer całunków słodki/ Owiewał cię, jak brzękiem pszczoły brzęczyzłotki (Gałąź I, 579). Poeta wykorzystał tu organizację foniczną tekstu, działając na zmysł słuchu czytelnika nagromadzeniem wyrazów ze spółgłoską szczelinową (szumiącą) sz: szum, szata, szeptat, szmer, pszczoła. Zaś w poetyckim porównaniu szum twych szat owiewat cię, jak brzękiem pszczoły brzęczyzłotki wystąpiła w członie określającym porównania podwójna waloryzacja dodatnia pszczoły, gdyż mamy brzęk pszczoły, czyli jej brzęczenie, jak brzęk upadającego złota oraz to, że jest ona barwy złotej, jak złoty jest kruszec.

Rzeczownik zlotoglów (4×) o zleksykalizowanej od dawna strukturze znany był, według Krystyny Długosz-Kurczabowej, w polszczyźnie od XVI wieku jako ‘tkanina o jedwabnej osnowie i wątku ze złotych nici, bardzo kosztowna, używana w dawnej Polsce na bogate stroje, szaty liturgiczne'21. W wierszach Staffa wystąpił w znaczeniu podstawowym w użyciach: ciężki złotogłów lśniący (Mistrz I, 166), drogie złotogłowie znosili (Gałąź I, 585), tkań złotogłowu (Uśmiechy I, 756); pajęcza tkań złotogłowu (W cieniu I, 934).

Przymiotniki złożone, w których drugi człon złożenia jest rzeczownikiem określanym przez przymiotnik złoty, złocisty

Analizie poddano kompozycje: zlotowtosy $(10 \times)$, ztotoktosy $(1 \times)$, zlocistoktosy $(1 \times)$, ztotobramny $(1 \times)$. W słowniku z epoki, w której kształtował się idiolekt poety, odnotowane zostały złożenia: złotowłosy ‘mający złote włosy’ (SW VIII, 537), złotokłosy 'mający złote kłosy, pokryty złotymi kłosami' (SW VIII, 535) - brak złocistokłosy, złotobramy 'mający złotą bramę' (SW VIII, 534) - brak złotobramny. Teresa Skubalanka tak pisze o tego typu złożeniach: „W związku ze słownictwem typowo poetyckim trzeba jeszcze wspomnieć o dwu kategoriach leksykalnych, które od wieków stanowią uderzającą cechę tego słownictwa: są nimi [...] epitety złożone. [...] Epitet złożony trafia się [...] jako powtórzenie znanego od dawna wyrazu [...] bądź jako neologizm oparty na tradycyjnym wzorcu słowotwórczym"22.

Przymiotnik złożony złotowłosy wystąpił jednokrotnie już w Trenie $X V$ Jana Kochanowskiego w znaczeniu 'mający włosy o barwie złota': Erato zlotowłosa $i$ ty, wdzięczna

${ }^{20}$ Opuszać 3. stp. 'odąć, nadąć, rozsadzić, rozdąć, rozpęczyć'; brak formy rzeczownikowej opusz (SW III, 819).

${ }^{21}$ K. Długosz-Kurczabowa, Stownik etymologiczny języka polskiego, Warszawa 2005, s. 548.

22 T. Skubalanka, O stylu poetyckim i innych stylach języka. Studia i szkice teoretyczne, Lublin 1995, s. 29 . 
lutni,/ Ską pociechę w swych troskach biora ludzie smutni!23 Maria Karpluk w podsumowaniu artykułu o języku poezji Jana Kochanowskiego pisze: „Kochanowski wprowadził do zasobów poetyckiego języka XVI w. szereg wyrazów, przeważnie złożonych (zebrano 63), które powtarzali po nim późniejsi twórcy. Niektóre z nich weszły na stałe do kulturalnej polszczyzny"24 - i tu wymienia między innymi złożenie złotowłosy, które ma utrwaloną obecność w języku poetyckim również kolejnych epok. W lirykach Leopolda Staffa - klasyka - wyraz ten posłużył do podkreślenia waloryzowanych dodatnio głów pięknych dzieci, kobiet i mężczyzn, np.: złotowłose dziewy (3×), (Dzień I, 315-317); złotowłosa córka (króla) (Ptakom I, 521); złotowłosa pani (Gałąź I, 585); złotowłosa skroń (W cieniu I, 923); piękne dziecię złotowłose (W cieniu I, 940); pieśniarz złotowłosy (Łabędź I, 1118), znacznie rzadziej w metaforach: śnić pieśń złotowłosa (Gałąź I, 659), czyli o dziewie złotowłosej lub złotowłose, różowe poranki (Łabędź I, 1090). W podobnych konotacjach semantycznych został zastosowany przymiotnik złoty $\mathrm{w}$ często używanym przez poetę epitecie nominalnym złote włosy, o czym pisałam w innym artykule ${ }^{25}$.

Staffowskie singularia: zlotoklosy, zlocistoktosy o parafrazach 'który ma kłosy złote/ złociste’ wystąpiły w dwu funkcjach. W sonecie V z cyklu Dzień pracy złożenie złotokłosy znalazło się w monologu wewnętrznym podmiotu na określenie wynurzeń duszy: Opuszczę chatę, nędzarz, w tachmanach i boso,/ Stawiąc Pana, że kośbę mi wziąt ztotoktosa,/ Cała nadzieję moja, synowska i wnuczą. (Dzień I, 377). Indywidualizm artystyczny Staffa ${ }^{26}$ zlocistokłosy został zastosowany w lirycznym opisie czteroletniej, wiejskiej dziewczynki w sonecie Gęsiarka: Krasa krajka przeplóttszy lnianowłosa kosę,/ Z kromka chleba w chusteczce za pasa przewiąka,/ Dłoń prawa uzbroiwszy wierzbiny gałazka,/ W lewej wlecze za soba źdźbło złocistokłose. (Ścieżki II, 175). Oba przymiotniki złożone mają identyczną strukturę podrzędną - tworzy ją w członie pierwszym przymiotnik złot(y), złocist(y), w członie drugim rzeczownik kłos. Człon przymiotnikowy nazywa cechę, człon rzeczownikowy - jej nosiciela ${ }^{27}$. Komponentami łączącymi złożoną formę gramatyczną są wykładniki formalne, to jest: interfiks - o- i morfem fleksyjny rodzaju męskiego $-y$.

Indywidualizm artystyczny Staffa złotobramny to derywat drugiego stopnia od rzadkiego w polszczyźnie złożenia podrzędnego złotobramy, powstałego z grupy nominalnej złota brama i sufiksu -ny. Poeta użył go w poemacie Mistrz Twardowski, w trzywersowej

23 J. Kochanowski, Dzieła polskie. Oprac. J. Krzyżanowski, Warszawa 1960, s. 610; Słownik polszczyzny Jana Kochanowskiego, pod red. M. Kucały, t. V (T-Ż), Kraków 2012, s. 748 .

${ }^{24}$ M. Karpluk, O języku poezji Jana Kochanowskiego. Dokończenie, „Język Polski” 1975, z. 2, s. 93.

25 Por. Obrazy poetyckie z komponentem barwy złotej w lirykach Leopolda Staffa, w: Barwa w języ$k u$, literaturze..., s. 80-81.

${ }^{26}$ Brak tego złożenia u Adama Mickiewicza, Stanisława Grochowiaka, Zbigniewa Herberta, Juliana Tuwima i Marii Pawlikowskiej-Jasnorzewskiej - patrz przypisy od 13 do 17.

${ }^{27}$ K. Kallas, Typy złożeń ze względu na charakter gramatyczny członów, w: Gramatyka wspótczesnego języka polskiego. Morfologia, cz. 2, pod red. R. Grzegorczykowej, R. Laskowskiego, H. Wróbla, wydanie drugie zmienione, Warszawa 1998, s. 513. 
strofie Śpiewu drugiego: O dziw, że wchodzim w prawdy ztotobramna/Świątynię, gdzie śnia wieczne tajemnice,/ My, dłonia twoja prowadzeni kłamną... (Mistrz I, 156).

\section{Przymiotniki złożone z dwu przymiotników prostych}

Chodzi tu o dwa złożenia: złotopłynny (1×) 'płynący, ciekący złotem, toczący złoto' (SW VIII, 536) oraz poetyzm semantyczny miodoplynny (1×) na określenie koloru tuniki tancerki. Przymiotnik złożony złotopłynny o parafrazie 'który jest jak płynne złoto', został utworzony dwoma przymiotnikami złoty, płynny, złączonymi interfiksem -o-. Semantycznie jest pośrednio wyrazicielem cechy dla rzeczownika $u l$ i tworzy metaforę przymiotnikową złotopłynne miodem ule w refleksyjnej zwrotce sonetu Wspomnienie: Ale czasem zdradziecki, nikczemny pasiecznik,/ Ograbiam świętokradczo zlotopłynne ule,/ Rozlewam miód, roztrwaniam po piasku i mule,/ A z wosku lepię bladą gromnice (Dzień I, 270).

Staffowski poetyzm semantyczny miodoplynny wyraża cechę o znaczeniu przeniesionym 'płynny jak (złoty) miód' dla nieosobowego nosiciela cechy - tuniki, co odnajdujemy w wierszu Zatarty fresk: Ciekawość mnie i troska dręczy nieustanna:/ Co robi śliczna morelowa panna,/ [...] W tunice miodopłynnej, w włosów aureoli,/ Tracała struny smukłej jako jej dłoń wioli (Martwa II, 739). Przymiotnik miodopłynny to neosemantyzm artystyczny poety, utworzony na zasadzie asocjacji z miodem, który jest zazwyczaj złotej barwy. W Słowniku warszawskim brak znaczenia kontekstowego, a pod hasłem miodopłynny czytamy: 1. 'słodko, łagodnie, mile płynący, mijający' (znane od J. Kochanowskiego), 2. 'przyjemnie mówiący, wymowny’ (I. Krasicki) (SW II, 993), podobne znaczenia podaje Słownik języka polskiego pod redakcją Witolda Doroszewskiego ${ }^{28}$. Metafora nominalna tunika miodopłynna zawiera podwójną waloryzację dodatnią: semantycznie odnosi się nie wprost do barwy miodu, a ze względu na drugi człon złożenia (przymiotnik płynny) wyraża ruch ubioru tancerki podczas tańca.

\section{Dwubarwne złożenia przymiotnikowe o podrzędnej (rzadko współrzędnej) strukturze}

Złożenia dwubarwne to grupa 13 przymiotników rzadko lub pojedynczo występujących w wierszach poety. Należą do nich wyrazy: modro-zloty $(3 \times)$, ztoto-modry $(1 \times)$, zielonozloty $(2 \times)$, zlotozielony $(1 \times)$, blękitnozłoty $(2 \times)$, zlotobłękitny $(1 \times)$, zloto-niebieski $(1 \times)$, krwawoztoty $(1 \times)$, purpurowoztoty $(1 \times)$, rudozloty $(1 \times)$, zlotordzawy $(1 \times)$, zlotoplowy $(1 \times)$, srebrnoztoty $(1 \times)$.

Zgodnie z zasadami pisowni polskiej dwubarwne złożenia przymiotnikowe pisane łącznie mają podrzędną zależność członów, w których człon pierwszy dookreśla znaczenie członu drugiego, natomiast w złożeniach pisanych z łącznikiem oba człony występują SJPD).

28 Stownikjęzyka polskiego, pod red. W. Doroszewskiego, Warszawa 1963, t. IV (L-Nić), s. 727 (dalej 
w relacji współrzędnej składniowo, to znaczy, że człon pierwszy i drugi są równorzędne. Kwiryna Handke w monografii Budowa morfologiczna i funkcje compositów polskich ${ }^{29}$ wielokrotnie potwierdza, na podstawie swoich badań, przewagę różnorodnych złożeń przymiotnikowych nad rzeczownikowymi w odmianach funkcjonalnych polszczyzny pisanej na przestrzeni wieków aż po czasy współczesne. Funkcję poetycką złożeń przymiotnikowych w języku utworów lirycznych wyraźnie podkreślała Teresa Skubalanka, o czym pisałam wcześniej.

Zgromadzone w tym artykule złożenia tworzą wąską grupę przymiotników dwubarwnych, w których jeden z członów jest wyrażony przymiotnikiem prostym złoty, drugi innym przymiotnikiem. Różnica tkwi w znaczeniach wynikających z podrzędnej lub współrzędnej relacji członów złożenia. W zbiorze 13 kompozycji przymiotnikowych przeważa stosunek podrzędny członów złożenia (10 przykładów) nad współrzędnym (3 przykłady).

Dla szerszej perspektywy badawczej i możliwości porównania złożeń przymiotnikowych, w których jeden z dwu członów zawiera przymiotnik złoty, przytaczam dane z badań nad funkcją barw w lirykach Adama Mickiewicza ${ }^{30}$, Stanisława Grochowiaka ${ }^{31}$, Zbigniewa Herberta $^{32}$, Marii Pawlikowskiej-Jasnorzewskiej ${ }^{33}$ i Juliana Tuwima ${ }^{34}$. Warto tu zaznaczyć, że jedynie badania Joanny Rychter nad barwami w lirykach Pawlikowskiej-Jasnorzewskiej i Adrianny Seniów o barwie złotej u Tuwima są porównywalne z moimi badaniami, gdyż ekscerpcja i analiza zjawisk są prowadzone według tej samej metody badawczej:

- Adam Mickiewicz (5 wyrazów): szczerozłoty, złotokłosy, złotowłosy, złoto-zielony, złotogłów;

- Stanisław Grochowiak (6 wyrazów): złotomigdałowy, ciemnozłoty, złotopalca, złotousty, złoto-świeży, złotogłowie;

- Zbigniew Herbert: złotolity;

- Maria Pawlikowska-Jasnorzewska (9 wyrazów): złotoblady, niebiesko-złoty, różowo-złocisty, siwozłoty, szczerozłoty, złotolity, złotopióry, złotogniady, złotowłosy;

- Julian Tuwim (7 wyrazów): biało-złoty, jasnozłoty, złoto-miodny, modro-złoty, szczerozłoty, złotopłynny, złotowłosy.

Leopold Staff dużo częściej wykorzystuje w swych lirykach przymiotniki złożone z komponentem barwy złotej, dlatego też jego kreacje świata przedstawionego mienią się różnorodnymi odcieniami złota. Analizę strukturalno-semantyczną dwubarwnych złożeń przedstawiam ze względu na miejsce przymiotnika złoty w złożeniu i wynikające z tego znaczenie kontekstowe wobec określanego rzeczownika. Równocześnie staram się

${ }^{29} \mathrm{~K}$. Handke, Budowa morfologiczna i funkcje compositów polskich (z uwzględnieniem innych języków zachodniostowiańskich), Ossolineum 1976.

30 Por. przypis 13.

31 Por. przypis 14.

32 Por. przypis 15.

33 Por. przypis 16.

34 Por. przypis 17. 
podkreślić bogactwo połączeń barwnych, które świadczą o wrażliwości poety na piękno otaczającej przyrody oraz niebywałą sprawność posługiwania się zasobami leksyki polskiej w kreacji świata przedstawionego liryków. Oto opis zjawisk:

- modro-zloty $(3 \times)$ a ztoto-modry ( $1 \times$ ), czyli modry i złoty oraz złoty i modry. Oba równorzędne składniowo przymiotniki barwne niezależnie od miejsca w złożeniu łączą się z rzeczownikami nazywającymi zjawiska typowe dla pory letniej, np.: $\boldsymbol{m o}$ dro-zlote/a jest: powietrze (Gałąź I, 625), szyba morza (Wysokie II, 598), bania - upojenia otchłań ‘letnia pogoda w czasie żniw’ (Barwa II, 687). Współrzędność członów złożenia w pełni oddaje grę obu barw niezależnie do tego, czy się patrzy na przestrzeń w górze, która może być modra, czy w układzie horyzontalnym, ale i wertykalnym, która jest złota i modra. Jednokrotnie użyte złożenie zloto-modry łączy się z rzeczownikiem abstrakcyjnym cudo w wierszu Dyskobol ziemi: Wszystko w krag byto jako ztoto-modre cudo,/ Kipiace rozrzutnościa szczęśliwej zieleni (W cieniu I, 923). Świat jest zatem złotym i modrym cudem, które kipi szczęśliwa zielenia, a więc i tu chodzi o letnią porę dnia;

- zielonozloty $(2 \times)$ a ztotozielony $(1 \times)$, czyli 'złoty z refleksami zieleni', rzadziej 'zielony z przebłyskiem złota'. W obu złożeniach występuje podrzędna zależność członów (człon drugi - nadrzędny, czyli określany, jest dopełniony barwą pierwszą - określającą), np.: mury malowane w mchy zielonoztote (Ptakom I, 449); wśród pól, co będa wnet zielonoztote (Żywiąc II, 408); czy to gwar polany zlotozielonej? (Ścieżki II, 142). Tu przymiotniki dwubarwne dookreślają zjawiska przyrody ożywionej, wyrażone rzeczownikami: mchy, pola, polana;

- błękitnozloty (2×) a zlotoblękitny (1×), tj. 'złoty z refleksami błękitnymi' lub 'błękitny z refleksami złotymi’, np.: lśni pogody blask blękitnozloty (Ścieżki II, 196); blękitnoztote morze (Wysokie II, 617); mgla zlotobtękitna (Sowim II, 331). Złożenia o budowie podrzędnej dookreślają rzeczowniki nazywające przestrzeń otwartą w układzie horyzontalnym (morze) i wertykalnym (blask pogody, mgła).

Poeta w kreacji przestrzeni nad ziemią, czyli nieba, używa głównie barwy błękitnej i modrej, rzadko niebieskiej ${ }^{35}$, stąd też tylko jeden przykład ze złożeniem zloto-niebieski, tj. 'i złoty, i niebieski'. W tym przymiotniku oba człony złożenia wystąpiły w relacji współrzędnej i posłużyły Staffowi do zobrazowania letniego poranka, który lśni złotem i niebieskością nieba: Poranek modrych mgiet drży podmuchem, /Wszystko jest takie zloto-niebieskie (Wysokie II, 606).

Dwa dwubarwne singularia przymiotnikowe mają obok barwy złotej przymiotnik barwny z pola czerwieni, czyli: krwawozloty i purpurowozloty, co ilustrują użycia tekstowe na określenie:

35 Pisałam o tym zjawisku w artykule: M. Białoskórska, Pole błękitu w lirykach Leopolda Staffa, w: Barwa w języku, literaturze i kulturze, cz. 2, pod red. E. Komorowskiej i D. Stanulewicz, Szczecin 2011, s. $103-125$. 
- pioruna: często piorun krwawozloty/ Uderzy i dobytek zniweczy w pożarze (Ścieżki II, 119);

- jesieni: przepych purpurowoztotych odcieni (jesieni) (Sowim II, 255).

Przymiotniki krwawozłoty, purpurowozłoty o parafrazie 'złoty z elementami barwy krwawej/ purpurowej’ zawierają w członie dookreślającym złożenia podrzędnego odcień o dużym natężeniu czerwieni: $\boldsymbol{k r w a w y}^{36}$, purpurowy ${ }^{37}$.

Kolejne dwa złożenia podrzędne: rudozłoty (1×) 'złoty z elementami rudości’ i złoto$\boldsymbol{r d z a w y}(1 \times)$ 'rdzawy z elementami złota’ mają w jednym z członów barwę ruda, czyli ‘śniado brudnoczerwoną (!), jak ruda; żółtoczerwoną' (SW V, 765), w drugim zaś rdzawa, czyli 'mającą kolor rdzy, rudawą' (SW V, 487). Przymiotnik rudozloty w wierszu Nów został zastosowany w porównaniu ilustrującym podmiot wiersza na tle zachodzącego słońca: stalem w słońca zachodzie jak płomień/ Rudoztoty, wysoki i chwiejny (Wiklina II, 896), zaś barwa zlotordzawa stała się określeniem żółknących liści w opisowej zwrotce sonetu Ostatnie zwiędty kwiaty: Ostatnie zwiędty kwiaty, zwarzone kasztany/ Sieja po szarej drodze liście złotordzawe (Labędź I, 996).

Ostatnie dwa singularia w wierszach poety to złożenia podrzędne: zlotopłowy 'płowy ze złotym połyskiem' i srebrnozłoty ‘złoty ze srebrnymi połyskami’. Kolor plowy ‘światło-szary, blado-żółtawy, barwy lnu’ (SW IV, 265) w połączeniu ze złotymi refleksami znalazł się w wierszu Elegia konającej jesieni, gdzie poeta zestawił włosy chorych kobiet z kolorem jesiennych drzew, np.: Od włosów kobiet, schorzałych samotnie,/ Wzięty swe barwy drzewa twe, jesieni!/ Z ich zlotopłowych warkoczy [...]/ Kobiet całunkiem śmierci naznaczonych. (Ptakom I, 454). Gatunek wiersza - elegia - zdeterminował powstanie opisu jesieni o barwie złotopłowej, którego bohaterkami są śmiertelnie chore kobiety, podczas gdy jesień w wierszach Staffa jest zazwyczaj piękna i wielobarwna. Z kolei podrzędne złożenie srebrnozloty wystąpiło w wierszu Gra chmur, o czym opisał Ryszard Tokarski ${ }^{38}$ w obszernym studium na temat semantyczno-składniowych właściwości wyrazu chmura. Przymiotnika srebrnozłoty użył poeta w jednym z wielu w tym wierszu opisów chmur, np.: Spójrz na nie! Stała zmienność, niestałość niezmienna,/Sennie-bezsenna;/ Niewierna gra, jak miłość, przysięga, pieszczota./Cóż żądać, jakby byta tęczowopromienna/ I srebrnoztota,/Nim ulegnie mrokowi, tej klątwie żywota? (Ścieżki II, 212). Barwa srebrnozłota oddaje tu dynamicznie zmieniającą się kolorystykę chmury o zachodzie słońca, które prześwituje przez obłok, tworząc złotą plamę ze srebrnymi refleksami aż po ciemny mrok.

${ }^{36}$ Krwawy-znaczenie 12. 'krwawoczerwony, koloru krwi’ z cytatami głównie z poetów romantycznych (SW II, 580-581).

${ }^{37}$ Purpurowy - 2. 'koloru purpury, czerwono-krwisty, szkarłatny' (SW V, 437).

${ }^{38}$ R. Tokarski, Modyfikacje znaczenia słowa w tekśsie poetyckim „Chmura” w poezji L. Staffa, w: idem, Znaczenie słowa i jego modyfikacje w tekście, Lublin 1987, s. 152-233. 


\section{Wnioski końcowe}

W kreacji świata przedstawionego liryków Leopolda Staffa wystąpiły 62 nazwy barw z pola złota, w tym dwa wyrazy rdzenne: złoty, złoto z morfemami końcówkowymi -y, -o, 49 derywatów prostych i złożonych z komponentem barwy złotej oraz poetyzmy semantyczne, które pominięto $\mathrm{w}$ opisie prócz złożenia miodopłynny.

Wśród derywatów przeważają przymiotniki złożone jednobarwne (10 wyrazów), np.: bladozłoty, złotowłosy, złotokłosy, miodopłynny i dwubarwne (14 wyrazów), np.: złoto-modry, purpurowozłoty, zielonozłoty itp. Znacząco mniej jest derywatów rzeczownikowych prostych (4 wyrazy), np.: pozłota, pozłótka, złocenie, złocistość i złożonych (2 wyrazy), np.: brzęczyzłotka, złotogłów oraz derywatów przymiotnikowych prostych (8 wyrazów), np.: złocisty, złocony, wyzłacany itp. Niewiele występuje również czasowników (11 wyrazów), wśród których znalazło się 9 derywatów czasownikowych (złocić, rozzłocić, złocić się) i 2 imiesłowy przysłówkowe współczesne (złocąc, złocąc się).

Wartość semantyczną nadawały prostym derywatom przymiotnikowym sufiksy: -isty $(29 \times)$, -ony $(12 \times),-a w y(3 \times),-n y(1 \times)$, np.: złocisty, złotawy, złocony, rozzłocony; w nielicznych derywatach rzeczownikowych wystąpiły sufiksy: -enie (1×), -ość (1×), -ka (1×), np.: złocenie, złocistość, pozłótka, a w grupie czasowników prefiksy: o- $(14 \times)$, po- $(3 \times)$, roz- $(1 \times)$ i postfiks się (19×), np.: ozłocić się, pozłocić się, rozzłocić się, rozzłacać się itp. przykłady.

W lirykach Leopolda Staffa wśród 33 derywatów przymiotnikowych (prostych i złożonych) aż 17 wyrazów to hapax legomena, które poeta zastosował głównie w opisach przyrody ożywionej i nieożywionej, rzadko natomiast dookreślają one elementy kultury materialnej. Należą do nich derywaty proste: pozłocisty, pozłocony; jednobarwne derywaty złożone: złocistokłosy, złotokłosy, złotobramny, złotodajny, złotopłynny, złotoszczery; dwubarwne derywaty złożone: złotobłękitny, złoto-niebieski, krwawozłoty, purpurowozłoty, rudozłoty, złotordzawy, srebrnozłoty, złotopłowy oraz neosemantyzm miodopłynna (tunika). Wszystkie są rejestrowane w tekstach lirycznych, co dokumentują źródła słownikowe (SW, SJPD) lub występują tylko w wierszach Staffa jako osobliwość języka badanych tu liryków.

Rzeczownikowe hapax legomena to trzy derywaty proste: pozłótka, złocenie, złocistość, które służą do podkreślenia materialnej wartości złota w opisie artefaktów. Ciekawą budowę ma natomiast neologizm artystyczny brzęczyzłotka, którym poeta nazwał synonimicznie pszczołę dla wyróżnienia jej przymiotów piękna i pracowitości.

Czasownikowe hapax legomena (przezłacać się, rozzłocić, rozzłacać się oraz złocac, złocac się) kreują poetyckie opisy stanów przyrody ożywionej i nieożywionej, wchodząc w skład niecodziennych metafor zmysłowych.

Na artyzm języka wierszy poety złożyła się znajomość bogactwa zasobu słownego ówczesnej polszczyzny, dar jego przetwarzania i łączenia w różnorodne konfiguracje, co pozwoliło tworzyć niecodzienne poetyckie figury stylistyczne, w których występowały wyrazy o różnej wartości funkcjonalnej i artystycznej. Wyrazy z komponentem nazwy barwy złotej i ich dystrybucja w lirykach Staffa - klasyka - wskazują na jeden z wielu szczegółów 
warsztatu artystycznego poety, co ilustruje zestawienie. Na łączną liczbę 739 użyć kolejne grupy zajmują:

- wyrazy najczęściej używane: złoty (451×), złoto (113×) - 564 użycia;

- wyrazy rzadko używane: złocisty (28×), złocić się (17×), ozłocićlozłacać (14×), złocić $(10 \times)$, złotowłosy $(10 \times)-79$ użyć;

- kolejne 14 wyrazów (patrz tabela) wystąpiło więcej niż 1 raz, a mniej niż 9 razy 70 użyć;

- hapax legomena - 26 wyrazów.

$\mathrm{Z}$ analizy badanego materiału wynika, że poeta wykorzystał takie techniki tworzenia derywatów przymiotnikowych, rzeczownikowych i czasownikowych z komponentem barwy złotej, które pozwoliły wyrazić: a) stopień osłabienia lub natężenia barwy (przymiotniki gradacyjne: złotawy, bladozłoty); b) istotę jakości barwy w relacji z określanym rzeczownikiem (np. przymiotniki jakościowe: złocisty, przezłocisty); c) zjawisko występowania stanu barwy (wykorzystanie czasowników stanowych, np.: złocić, złocić się, ozłacać, rozzłocić; rzeczowników dewerbalnych, np. złocenie); d) stopień metaforyzacji syntetycznych form przymiotnikowo-rzeczownikowych w miejsce grup nominalnych (np.: złotowłosy, złocistokłosy, złotobramny) oraz e) przymiotników dwubarwnych (np.: zielonozłoty, modro-złoty, krwawozłoty, złotopłowy), co wpłynęło na ekonomię wypowiedzi poetyckiej. Dzięki temu stworzył Staff barwne językowe kreacje przyrody ożywionej i nieożywionej, ukazał waloryzowane dodatnio opisy złotych włosów wybranych postaci i piękno artefaktów tworzących kulturę materialną ludzi.

\section{Źródła}

(W porządku alfabetycznym podaje się za skrótem pełną nazwę zbiorku)

Barwa - Barwa miodu (1936)

Dzień - Dzień duszy (1903)

Gałąź - Gałąz kwitnąca (1908)

Łabędź - Łabędź i lira (1914)

Martwa - Martwa pogoda (1946)

Mistrz - Mistrz Twardowski (1902)

Ptakom - Ptakom niebieskim (1905)

Sny - Sny o potędze (1901)

Sowim - Sowim piórem (1921)

Ścieżki - Ścieżki polne (1919)

Tęcza - Tęcza łez i krwi (1918)

Ucho - Ucho igielne (1927)

Uśmiechy - Uśmiechy godzin (1910) 
W cieniu - W cieniu miecza $(1911)$

Wiklina - Wiklina (1954)

Wysokie - Wysokie drzewa (1932)

Żywiąc - Żywiac się w locie (1922)

\section{Bibliografia}

Badyda E., Świat barw - świat znaczeń w języku poezji Zbigniewa Herberta, Gdańsk 2008.

Białoskórska M., Obrazy poetyckie z komponentem barwy złotej w lirykach Leopolda Staffa, w: Barwa w języku, literaturze i kulturze, cz. 4, pod red. E. Komorowskiej i D. Stanulewicz, Szczecin 2013, s. 71-84.

Białoskórska M., Pole błękitu w lirykach Leopolda Staffa, w: Barwa w języku, literaturze i kulturze, cz. 2, pod red. E. Komorowskiej i D. Stanulewicz, Szczecin 2011, s. 103-125.

Białoskórska M., Stratyfikacja słownictwa z komponentem nazwy barwy złotej w lirykach Leopolda Staffa, „Studia Językoznawcze”. Synchroniczne i diachroniczne aspekty badań polszczyzny, Szczecin 2015, t. 14, s. $25-41$.

Handke K., Budowa morfologiczna i funkcje compositów polskich (z uwzględnieniem innych języków zachodniostowiańskich), Ossolineum 1976.

Kallas K, Derywaty gradacyjne, w: Gramatyka wspótczesnego języka polskiego. Morfologia, cz. 2, pod red. R. Grzegorczykowej, R. Laskowskiego, H. Wróbla, wydanie drugie zmienione, Warszawa 1998, s. 502.

Kallas K., Typy złożeń ze względu na charakter gramatyczny członów, w: Gramatyka współczesnego języka polskiego. Morfologia, cz. 2, pod red. R. Grzegorczykowej, R. Laskowskiego, H. Wróbla, wydanie drugie zmienione, Warszawa 1998, s. 513.

Karpluk M., O języku poezji Jana Kochanowskiego. Dokończenie, ,Język Polski” 1975, z. 2, s. 93.

Kochanowski J., Dzieła polskie. Oprac. J. Krzyżanowski, Warszawa 1960.

Kurek M., Kolor w poezji Stanisław Grochowiaka, „Poznańskie Studia Polonistyczne”. Seria Językoznawcze, Poznań 1997, s. 132-147.

Laskowski R., Paradygmatyka. Czasownik, w: Gramatyka wspótczesnego języka polskiego. Morfologia, cz. 1, Warszawa 1998, s. 191-192.

Maciejewska I., Leopold Staff. Lwowski okres twórczości, Warszawa 1965.

Maciejewska I., Leopold Staff. Warszawski okres twórczości, Warszawa 1973.

Rychter J., Językowa kreacja barw w poezji Marii Pawlikowskiej-Jasnorzewskiej, Szczecin 2014.

Seniów A., Barwa złota w utworach lirycznych Juliana Tuwima, „Studia Językoznawcze”. Synchroniczne i diachroniczne aspekty badań polszczyzny, Szczecin 2012, t. 11, s. 187-207.

Skubalanka T., O stylu poetyckim i innych stylach języka. Studia i szkice teoretyczne, Lublin 1995.

Tokarski R., Modyfikacje znaczenia słowa w tekście poetyckim „Chmura” w poezji L. Staffa, w: idem, Znaczenie stowa i jego modyfikacje w tekście, Lublin 1987, s. 152-233.

Tokarski R., Semantyka barw we współczesnej polszczyźnie, Lublin 1995, s. 116-119.

Winkler-Leszczyńska I., Sufiksy przymiotnikowe -ity, -isty, -aty, -asty w języku polskim na tle ogólnostowiańskim, Ossolineum 1964, s. 15. 


\section{Słowniki}

Długosz-Kurczabowa K., Stownik etymologiczny języka polskiego, Warszawa 2005.

Stownik języka Adama Mickiewicza, pod red. K. Górskiego, S. Hrabca, t. 1-11, Wrocław 1962-1983.

Słownik języka polskiego, pod red. W. Doroszewskiego, t. IV (L-Nić), Warszawa 1963.

Słownik języka polskiego, pod red. J. Karłowicza, A. Kryńskiego, W. Niedźwiedzkiego, t. 1-8, Warszawa 1900-1927.

Stownik polszczyzny Jana Kochanowskiego, pod red. M. Kucały, t. V (T-Ż), Kraków 2012.

\section{Strukturalno-semantyczna analiza słownictwa \\ z komponentem nazwy barwy złotej w lirykach Leopolda Staffa (część trzecia)}

\section{Streszczenie}

$\mathrm{Z}$ analizy badanego materiału wynika, że poeta wykorzystał takie techniki tworzenia derywatów przymiotnikowych, rzeczownikowych i czasownikowych z komponentem barwy złotej, które pozwoliły wyrazić:

a) stopień osłabienia lub natężenia barwy (przymiotniki gradacyjne: złotawy, bladozłoty);

b) istotę jakości barwy w relacji z określanym rzeczownikiem (np. przymiotniki jakościowe: złocisty, przezlocisty);

c) zjawisko występowania stanu barwy (wykorzystanie czasowników stanowych, np.: złocić, złocić się, ozłacać, rozzłocić; rzeczowników dewerbalnych, np. złocenie);

d) stopień metaforyzacji syntetycznych form przymiotnikowo-rzeczownikowych w miejsce grup nominalnych (np.: złotowłosy, złocistokłosy, złotobramny) oraz

e) przymiotników dwubarwnych (np.: zielonozłoty, modro-złoty, krwawozłoty, złotopłowy), co wpłynęło na ekonomię wypowiedzi poetyckiej. Dzięki temu stworzył barwne językowe kreacje przyrody ożywionej i nieożywionej, ukazał waloryzowane dodatnio opisy złotych włosów wybranych postaci i piękno artefaktów tworzących kulturę materialną ludzi.

Structural and semantic analysis of the vocabulary with a component of the name of one colour - złoty 'gold(en)' - in the lyric of Leopold Staff (part three)

Su m m a r y

An analysis of the material shows that the poet used such techniques of creating adjectival, substantive and verbal derivatives with a component of a golden colour that made it possible to express:

a) a degree of subduing or intensifying the colour (gradual adjectives: goldish (Polish: złotawy), pale gold (Polish: bladozloty);

b) the essence of the colour in relation to an accompanying noun (for example, qualitative adjectives: golden/amber (Polish: złocisty), super golden/amber (Polish: przezłocisty); 
c) the phenomenon of a colour state (using verbs that describe a state: to gild, to shine like gold, to take on a golden colour [złocić, złocić się, ozłacać, rozzłocić]; verbal nouns: złocenie);

d) a degree of metaphorising of synthetic adjectival-substantive forms instead of nominal groups (for example, złotowlosy 'with golden hair (golden-haired)', złocistokłosy 'of golden spikes (ears of grain)', złotobramny 'of/with (a) golden gate(s)';

e) adjectives containing two colours (for example, zielonozłoty golden green, modro-złoty 'golden (dark) blue', krwawozłoty 'golden blood-red', złotopłowy 'golden tawny');

which affected the economy of his poetic expression. Thanks to the above-mentioned techniques the poet created a colourful language to describe animated and inanimate nature; he provided positively valorised descriptions of golden hair of some characters and the beauty of the artefacts that create material culture of the people. 